\title{
Architecture_MPS
}

\section{Art, Architecture and the Law: The Architectural Project and the Legal Contract as Social Artefacts}

Anne Bordeleau ${ }^{1}$, André Bélanger ${ }^{2}$

How to cite: Bordeleau, A., Bélanger, A. 'Art, Architecture and the Law: The Architectural Project and the Legal Contract as Social Artefacts.' [Architecture_MPS], 2014, 4(1): 3, pp. 1-17. DOI: https://doi.org/10.14324/111.444.amps.2014v4i3.001.

Published: 01 March 2014

\section{Peer Review:}

This article has been peer reviewed through the journal's standard Editorial double blind peer review.

\section{Copyright:}

(C) 2014, The Author(s). This is an Open Access article distributed under the terms of the Creative Commons Attribution License (CC-BY) 2.0 https://creativecommons.org/licenses/by/2.0/, which permits re-use, distribution and reproduction in any medium, provided the original author and source are credited • DOI: https://doi.org/10.14324/111.444.amps.2014v4i3.001

\section{Open Access:}

Architecture_MPS is a peer-reviewed open access journal. 


\title{
Title: Art, Architecture and the Law: The Architectural Project and the Legal Contract as Social Artefacts
}

\section{Author: Anne Bordeleau and André Bélanger}

\author{
Architecture_media_politics_society. vol.4, 1no.3.
}

March 2014

Affiliation: University of Waterloo, Ontario, Canada; Université Laval, Quebec, Canada

\begin{abstract}
:
In an installation presented at the Cooper Gallery in New York in 2005, the British-American artist Carey Young located six vinyl lines on the floor and walls of a room. She then placed an inscription announcing that the American Constitution would temporarily not apply to those who decided to stand within the space defined by the lines. In this political yet playful installation entitled Declared Void, Young points to the grey zones of the legal system, while also questioning the social role of architecture, and even our understanding of what constitutes a defined space. In a piece entitled Double Game, 1999, the artist Sophie Calle worked with Paul Auster in a performance piece in which they mutually entered a contract according to which Calle played the role of a character in one of Auster's novels. It involved her deliberately appropriating various sites in New York City in such a way that the accepted conventions of their public use were overturned. Converting, for example, a telephone booth into a decorated interior space for private use she temporarily broke basic spatial contracts about the shared use of spaces in the city while, simultaneously, placing the 'contract' at the center of the work.
\end{abstract}

Similarly, the Spanish artist Santiago Sierra has played with notions of the contract and our contractual use and reading of spaces in works such as A line of $160 \mathrm{~cm}$ tattooed on 4 people, 2000, in which he uses the gallery setting as a spatial symbol that 'legitimizes' the contracting of four prostitutes in an agreement that allows their bodies to be indelibly marked in the name of an art performance. Following a tradition evident since the 1950s, the work of these artists has used the notion of the contract and the social ambiguities of space in a way that has either been foregrounded in their final pieces, or is indispensable to the discomfort created by their work. Operating in a blurred legal and spatial zone, these artists question the jurist's notions of the contract and the architect's ideas of space. As a result, they also open up both disciplines to a cross disciplinary reading that investigates their real and conceptual overlaps. In creating works that invite a 'contractual' (and thus immaterial) reading of physical space and an examination of the 'real' (and thus material) consequences of the contract they allow us to consider issues of direct importance to the theory of law; architecture's role in contemporary society; and how a cross disciplinary perspective of these issues potentially opens architecture and the contract - understood as social artefacts - to the full implications of a reading through the prism of Hannah Arendt's 'subjective in-between' - a realm in which the "intangible is no less real than the world of things we visible have in common". 


\title{
Title: Art, Architecture and Law: The
} Architectural Project and the Legal Contract as Social Artefacts

\author{
Authors: Anne Bordeleau and André Bélanger
}

Architecture_media_politics_society. vol.4, no.3.

March 2014

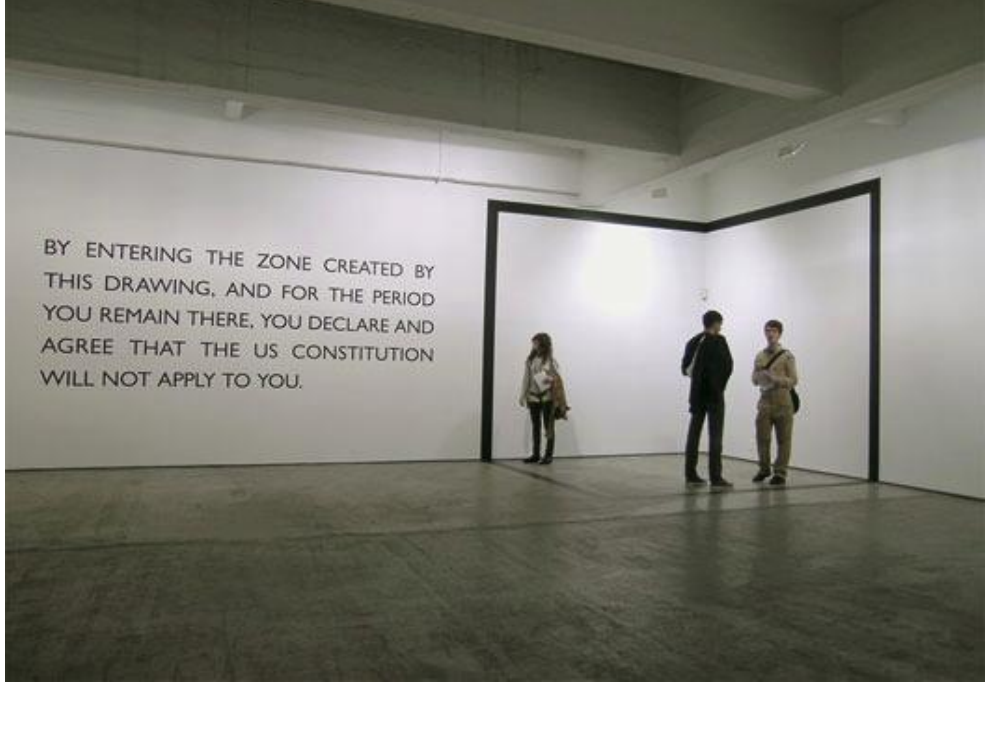

Carey Young, Declared Void, 2005. Photograph by authors

[The] subjective in-between is not tangible, since there are no tangible objects into which it would solidify; the process of acting and speaking can leave behind no such results and end products. But for all its intangibility, this in-between is no less real than the world of things we visible have in common. We call this reality the web of human relationships, indicating by the metaphor its somewhat intangible quality. (Arendt, 1970, p. 193). 


\section{Amps}

In an installation presented at the Cooper Gallery in New York in 2005, the British-American artist Carey Young located six vinyl lines on the floor and walls of a room. She then placed an inscription announcing that the American Constitution would temporarily not apply to those who decided to stand within the space defined by the lines. In this political yet playful installation entitled Declared Void, Young points to the grey zones of the legal system, while also questioning the social role of architecture, and even our understanding of what constitutes a defined space. In a piece entitled Double Game, 1999, the artist Sophie Calle worked with Paul Auster in a performance piece in which they mutually entered a contract according to which Calle played the role of a character in one of Auster's novels. It involved her deliberately appropriating various sites in New York City in such a way that the accepted conventions of their public use were overturned. Converting, for example, a telephone booth into a decorated interior space for private use she temporarily broke basic spatial contracts about the shared use of spaces in the city while, simultaneously, placing the 'contract' at the center of the work.

Similarly, the Spanish artist Santiago Sierra has played with notions of the contract and our contractual use and reading of spaces in works such as A line of $160 \mathrm{~cm}$ tattooed on 4 people, 2000, in which he uses the gallery setting as a spatial symbol that 'legitimizes' the contracting of four prostitutes in an agreement that allows their bodies to be indelibly marked in the name of an art performance. Following a tradition evident since the 1950s, the work of these artists has used the notion of the contract and the social ambiguities of space in a way that has either been foregrounded in their final pieces, or is indispensable to the discomfort created by their work. Operating in a blurred legal and spatial zone, these artists question the jurist's notions of the contract and the architect's ideas of space. As a result, they also open up both disciplines to a cross disciplinary reading that investigates their real and conceptual overlaps. In creating works that invite a 'contractual' (and thus immaterial) reading of physical space and an examination of the 'real' (and thus material) consequences of the contract they allow us to consider issues of direct importance to the theory of law; architecture's role in contemporary society; and how a cross disciplinary perspective of these issues potentially opens architecture and the contract - understood as social artefacts - to the full implications of a reading through the prism of Hannah Arendt's 'subjective in-between' - a realm in which the "intangible is no less real than the world of things we visible have in common".

In this subjective in-between, these artists participate in the larger socio-juridical economy sanctioned by the museum (as building and institution) which allows them to criticize the world within which they operate. In these contexts we shall argue that the contract seems to have, on occasion, allowed social injustices to be ratified in the name of art and entertainment rather than act as an independent instrument of legal justice intended to ensure the protection of individuals and groups. In the same way, we shall suggest that the architecture of the setting seems to have become a form of contractual guarantor of these 'injustices' and exploitative acts by operating as a legitimizing spatial symbol. In this process, both the contract and the museum become a commodity in a capitalist economy's drive to entertainment; multiple questions get raised about the nature and boundaries of public and private space; and the notion of what contracts we enter into when we occupy public spaces are fundamentally challenged and reconfigured.

While the idea of artistic practices critically asking questions about the social context in which they operates is by no means novel, what is of particular interest in these performances - displayed as spectacles in different spatial venues - is how they foreground the crucial and complex dimensions of the contract and of architecture as social artefacts. ${ }^{1}$ As a result, it the premise of the authors of this piece - an 
architect and a jurist - that to fully understand and analyse these works and their implications for our reading of architecture and the contract as social artefacts, it is necessary to apply a cross disciplinary perspective - what we call, a "double tangential" approach. ${ }^{2}$ This cross disciplinary consideration of the intersection between law and architecture hopefully enables us to reach a much more unpredictable and diverse public. ${ }^{3}$ It also allows us to add a unique critical perspective to a large and growing body of literature currently in development by various other researchers in these related fields. ${ }^{4}$

\section{Carey Young playing and voiding}

In Declared Void, 2005, Carey Young used simple lines to define a space where the American Constitution would not apply. The installation was part of the larger exhibition entitled Consideration, for which Young worked in collaboration with jurists. In her presentation of the work, she described it as "a playful take on the rampant litigation and legal limbos of contemporary cultural life." ${ }^{5}$ Directly integrating a juridical discourse in her work, Young's show was principally based on these fictitious contractual relations that involved the museum-goer engaging with her ideas:

My show explored law as a context, a kind of "stage," for art. "Consideration", the title of the show, has multiple meanings: as well as signifying the act of thinking, it conflates the idea of payment and exchange with notions of respect and kindness. It's also a central term within contract law, meaning something promised or done between two or more parties that leads to a legally enforceable contract. ${ }^{6}$

Architecturally, Declared Void presents six intersecting lines on three different faces of one of the gallery's interior corners. This layout is completed by a clear statement on one of the two walls: "By entering the zone created by this drawing, and for the period you remain there, you declare and agree that the US Constitution will not apply to you." ${ }^{7}$

Young was of course aware of the juridical lacunae of her installation, and this is precisely what enabled her to take a critical stance on the institution of the contract in Western society. What is more, she actually played on the length of the contractual agreement, the geographical location of the work, and the physical displacement of the viewer. As such, she was questioning both the limits of consensualism from a temporal perspective rarely adopted in law, and the geographical-statutory contradictions of a world overlaid with multiple legal definitions and jurisdictions. Discussing the project, she points to the spatial and temporal play that fictionally takes the visitors out of one legal jurisdiction as they enter into an agreement with the artist:

That designated space in the corner of the gallery, outlined by a wall drawing, lies outside the U.S. Constitution because the artist declares it so, and by entering that corner space 
you are signifying that you agree with the artist. That's a contract, so by entering the corner space you are contractually bound to the artist - temporarily speaking. The more permanent contractual works, which bind the viewer to the artist for longer periods, come elsewhere in the show. ${ }^{8}$

A number of questions emerge from this: What impact does the work have both on our conception of the institution and of the museum? How does it affect our understanding of place? What are its implications for a definition of space - how do six lines in the corner of a room have the power to become a free zone? How can the museum building confer credibility on this act? How can the jurist make rational sense of the questions that Young's raises about the contractual agreement and the concurrence of wills?

Spatially, the artist plays with a number of territories - fitting one into the other like a set of Matryoshkas that cross different boundaries and respond to diverse rules. Firstly, there is the national territory - the country in which the exhibition is taking place. Secondly, there is the museum location - an institution synonymous with a double social role. Thirdly, there is the space of the artwork itself - defined by the white lines on the ground and walls. This raises questions such as whether, in this taped-up border, one is still inside the institution of the museum, or even in the United States - and what constitutes both these spaces? It also questions the legitimacy of borders and their arbitrary demarcation. The piece was shown at the Paula Cooper Gallery in 2005 and at the Museum of Art at the Rhode Island School of Design in 2010. If it eventually travels outside the United States of America, it is apt to ask what happens to its claim to be a space in which the constitution no longer applies.

These questions overlap with issues around the museum itself. The museum is a form of extra-territorial land not confined to the country in which it is located, and through which various travelling exhibitions stop. It may have stronger links to other museums or galleries around the world than it has the actual country in which it sits. As such, it constitutes a territory in its own terms. The museum is also a space, and an institution, that allows a certain intellectual playfulness for its visitors. In this case specifically, but in all museums generally, visitors can momentarily suspend the social rules and laws that bind them they can accept the notion of stepping out of one territory and into another, at will. Although playful, this act is not a meaningless one. It allows the work to ask where, and how, the territory inside the vinyl tape is actually constituted and what it means to enter into it. If we cross the border defined, are we in a space of pure contestation or pure apathy? Are we actively engaging in a deliberate act of protest or agreement, or simply responding passively to the expected norms of behaviour in this specific artistic setting?

In a more architectural-spatial consideration of the piece itself, there emerges an interesting ambiguity about the spatial frame provided. The visitor must mentally project the lines upward and across to complete the enclosure suggested by tape and the three planes - the floor and the two intersecting walls. In ways that echo the work of Kazimir Malevich ${ }^{9}$, Young's piece operates simultaneously in different spatial registers. However, as also in the case of Malevich, it also operates at different temporal levels too - the moment defined by one's stepping inside the marked-out area defines a distinct temporal moment in the work; the duration of our presence inside is another; the time-scale of the exhibition in different museums is a third. Spatio-temporally, the piece is a complex one. However, it is also a work based on 
the consideration of the contract. ${ }^{10}$ From a juridical perspective, the contract here is used to critique the legal environment and the constitution of borders generally. It questions ideas as fundamental as what makes 'nationhood'; how are the rules and the spaces of the law defined, constructed and implemented; how do we define and accept the notion of territorial sovereignty; who has the right to define one space as distinct from another in this, or any other context.

Beyond these questions, it is also arguable that visitors who engage with the piece are also asked to question the legal constrictions within which artists inevitably operate - and into whose grey areas they are invited to step. Similarly, the socio-economical role of the contract in contemporary society means that the work potentially points to issues of everyday concern. Furthermore, given that the majority of us enter the unregulated contracts of contemporary society passively, it can also highlight how difficult it is to reach an equilibrium between the 'tool of autonomy' the contract potentially represents for an active individual, and the legal trap that it potentially constitutes for a passive subject. The controversial role of the contract this work brings to the fore should not be ignored by jurists as it touches on the epistemological boundaries of legal discourse. Even though it comes from outside the professional discipline, its questions offer a potentially important contribution to juridical criticism.

\section{Sophie Calle testing the intimate}

In the work of Sophie Calle, the questions posed by the artist are both more personal and more open. They are more personal because the notion of the contract specifically relates to the artist's personal definition of boundaries and codes of conduct. "Under contract" Calle says, "I can do everything," 11 and by this she means either having strangers sleep in her bed, asking personal questions, or breaching someone else's intimacy. An otherwise unobtrusive person, Calle allows herself to do a range of different activities that flirt with illegality because she defines specific rules for each of her artistic explorations. She then diligently follows these rules as though they were the terms of a contract she had agreed to. The contractual engagement takes a very personal form. It is an unwritten rule set for oneself that becomes public only in its position at the core of an art work that is subsequently published or exhibited. It also manifests itself as a set of rules that others follow, namely, the participants in her works. In this scenario, she personifies both the hand that writes the terms of the contract, and the one that accepts them; a doubling that enables her to personify both parties of the synallagmatic contract. In contrast to the case of Young, where the contract between the artist and the gallery-goer is indirect or, as we shall see in the case of Santigao Sierra, the contract is between clearly unequal parties, the contracts made in the work of Calle would appear to be between knowing and equal parties. However, when we probe the question a little more, the consensualism at the heart of these contracts is not quite as clear as it first seems. It is a valid question to ask how personal do Sophie Calle's agreements remain after she opens her work for the world to consider. From a social perspective, viewers may have accepted the terms she set in their interpersonal contracts, but their participation becomes part of an enlarged agreement in a displayed artwork and this effectively changes the terms and scope of the original contract. Contractually then, her work raises a number of issues for the jurist. 


\section{Amps}

The questions Calle's work poses are also more open than those of Young because her practice challenges and expands the traditional domain of art. She makes private and public spaces - the city, the world, and the heart of an individual - the site for her work. Visitors to Venice become matter to be sculpted into artistic interventions; hotel rooms become studio spaces; and Calle's own life and body become something to be 'exploited' in the name of art. Spatially, we are no longer in the territorial and political space of Young, but in the phenomenological world of an artist willingly playing with personal, legal and institutional overlaps. ${ }^{12}$ Spatially however, we are in a sphere in which our common expectations of the personal appropriation of public spaces are challenged and, through that, our very understanding of "the public' is questioned. Theoretically, we tend to think of public space as the space of the public, where the many can come together as though with one mind. ${ }^{13}$ In reality however, the public spaces - the truly common and shared realms of our cities - are much more complex phenomena than this. They are spaces of unspoken desires, multiple aspirations and conflicting perceptions. They are the realm in which contradicting readings, actions, behaviours and thought can, and do, co-exist.

Picking up on these themes in her 2002 installation, Chambre avec vue, 2002, Calle appropriated the Eiffel Tower and the actions that normally take place there. In this piece, a bed is brought up to the top floor of the tower and made into an impromptu 'room'. Visitors come up to tell her stories, instructed (contracted) to prevent Calle - who wears her nightgown - from falling asleep. Three hundred and nine meters above the city of Paris, Calle conflates actions, behaviours and expectations of spaces - the tourist becomes a player in an art work, the Eifel Tower an art gallery or private room, and the bed an art object. Reflecting a theme at the heart of the writings and theories of, amongst others, Bernard Tschumi, ${ }^{14}$ the piece paradoxically makes these various spaces - those of the work, the room, the building and the city appear for what they really are: not the sites of a unique and shared experience and set of emotions, but potentially emancipatory spaces where conflicting desires, actions and behaviours inevitably co-exist.

In another work, Double Game, developed with Paul Auster, she entered into what she refers to as a contractual agreement with the writer, whereby she accepted to become a 'real' fictional character in one of his stories - both contributing to his story through her own actions, and also acting out in 'real life' what she imagined was contained in his work. ${ }^{15}$ In the personal instructions that Paul Auster gives to Sophie Calle he tells her "to improve her life in New York" ${ }^{16}$ More specifically, he encourages her to transgress acceptable social behaviours in what is normally considered shared public space. Instructed to "adopt a public space," Calle appropriates a phone booth to herself. She paints the floor green, arranges postcards, places an ashtray inside and brings some flowers to decorate its interior. The work, in its entirety, lays bare a myriad of such 'contractual transgressions' in our use of spaces and questions the social legitimacy, or lack thereof, of certain actions in certain spaces: the occupation of a park bench and its use as a bed by a homeless person; the use of a recessed door as protection from the weather on a cold winter's night; the employment of the phone booth as a public toilet that offers some intimacy to its 'user' etc.

In other pieces Calle has asked strangers to sleep in her bed continuously while she sat, in close proximity, watching them sleep; she has 'contracted' 107 women to comment on an email received by a lover in which he was putting an end to their relationship; ${ }^{17}$ and in Suite Vénitienne, 1980, she got agreement (effectively formed a contract) to follow a man, Henri B, for 13 days on a trip to Venice. ${ }^{18}$ As in the case of Carey Young's art, what is common to all these works is the crucial, if subtle, role that the 
personal contract takes - and the critical questioning of typically accepted spatial boundaries it invokes. They are works that place the contract at the fore of the way they function; that call into question the public and / or private nature of the contract; and which, in socio-spatial terms, foreground the urgency of envisioning a public space that is truly open to a socially diverse public. On multiple and simultaneous levels then, Calle's work challenges our fundamental understanding of what is public or private; what is shared or personal; what is real or fictitious; what is the space of our life and that of art or the museum or gallery.

\section{Santiago Sierra delimitating the social}

Santiago Sierra, a Spanish artist now residing in Mexico, has been using contracts for over 20 years to involve a number of vulnerable individuals (prostitutes, drug addicts, the unemployed, homeless people and illegal immigrants, amongst others) in his works. In the context of different artistic venues he has paid people to engage in a series of acts that seem to have little, if any, social sense. He has paid people to stand still in a cardboard box (Germany, 2000); be locked up in a car trunk (Ireland, 2000); to clean people's shoes without their consent (Mexico, 2000); to lie down in wooden boxes during a celebration (Cuba, 2001); to move concrete blocks inside an art gallery (Bregenz Kunsthaus, Austria, 2002); and even to have themselves buried (Italy, 2010). These artistic performances have been documented either through videos or photographs and later exhibited in some of the largest museums in the world - PS1 in New York, The Kunst-Werke in Berlin and the Tate Modern in London. In a particularly disturbing work, $A$ line of $160 \mathrm{~cm}$ tattooed on 4 people, the limits of contractual permissiveness were pushed to an extreme. In this work, at the El Gallo Arte Contemporáneo (Salamanca, Spain) in December 2000, the contractual agreement gave Sierra permission to have a black line, measuring $160 \mathrm{~cm}$, tattooed on the back of four prostitutes addicted to heroin, and to film the act as a performance piece. ${ }^{19}$ In exchange, the prostitutes were given 12,000 pesetas - the price for a dose of heroin, or four to six times the amount received for oral sex. ${ }^{20}$

The film shows the four women seated - their back to the camera - laughing, talking and smoking as a tattoo artist draws the line. The artist is dressed symbolically in red and, periodically, two men in dark clothes appear on screen to measure the length of the line. They also take photographs. ${ }^{21}$ The women are filmed from behind so the viewer sees their backs. The variously arranged lights cast an array of shadows on the white wall in front of them. An audience is visible on screen. The simple set is quasi clinical - the white museum walls standing in for those of a hospital as the viewer focuses on the gloved hand that holds the needle. Only here, the bystanders are not nurses but avid art viewers and the focus is not on health but ent'art'ainment. ${ }^{22}$ The contractual, physical, and artistic staging all contribute to the revelation of the different relations that lie at the heart of this performance: men-women, prostitutes-clients, employer-employed, dominating-dominated, etc. Exhibiting four individuals who, because of pressing financial need, accept this meaningless and indelible black line, Sierra reveals not only the consensualism of the contract, but the lack of real options available to some members of the poorer strata of society when they enter in the myriad of contracts that regulate social life. 
The fact that the whole process takes place in a museum, and is documented so as to be displayed in other art venues, adds to the questions being raised. The walls of the museum not only give a quasi-clinical feel to the events, but also confer the 'objectivity' and 'legitimacy' of the museum institution. Indeed, this can be said to be essential to the creation of the normative intellectualized space in which this quasi-illicit activity, and the contract underlying it, can be considered legitimate. Presenting this work as art, and conferring it with the legitimacy of the gallery setting, allows a distance to emerge between the reality (and the pain of those being tattooed) and the spectacle of watching (the intellectual titillation of ent'art'tainment). This distancing is augmented when the video of the piece is shown in other locations around the world, and thus further integrated into the ent'art'ainment phenomenon. For gallery visitors in these distanced venues, the experience of going to a gallery is often, in itself, seen as something separate - and therefore somewhat detached from normal everyday life. In this specific case, what is being witnessed by the distanced viewers however, is the documentation of the difficulty of someone's actual life - a revelation and commentary on the harshness of some people's 'real' existence. The implicit contract we agree to when we enter a museum - that the activities it presents and our viewing of them is legitimate - not only allows what is clearly a form of exploitation, it does so in a format that can be defined as 'entertainment'.

Drawing attention to these questions is of course what the work is about and this questioning is in fact heightened by the distancing. When shown at the Lisson Gallery in 2012: for example, the chairs provided for the viewers' face those of the film's four protagonists. Although the neutrality of this second space can again be said to come into play - the second clinical setting attributing another layer of objectivity and intellectual credibility to the proceedings - these distanced visitors were explicitly made aware of both the comfort provided them as they watch the deed performed, but are also placed in a position that 'stands-in' for that of the real protagonists. In this way, the museum-goers, as willing participants in the cultural event, are forced to face the fact that their engagement is akin to voyeurism from the height of a dominating position at best and, in a harsher reading, equates to a form of exploitation in the context of intellectualized entertainment.

Related issues were raised in an installation presented at the Tate Modern Museum in 2008 in which Sierra paid nine homeless women to face a wall and stay still - in exchange for a night in a hostel. They were asked to stand with their back to the public, facing the wall, as though they were being punished. For an hour, they stood like this in the Turbine Hall while visitors circulated, stopped, observed and wondered, ill at ease, with this staged relation. ${ }^{23}$ The contractual relation between artist, gallery and figurants here was evident, but the 'contractual agreement' into which the visitors too had implicitly entered was obvious and, by bringing this into play, the piece destabilized, at least momentarily, the comfortable expectations and beliefs of its audience - creating the sought-for questioning of the piece and its consequential discomfort. ${ }^{24}$ The vast space of the Turbine Hall provided a gargantuan context against which all played their roles - the paying visitors (not really knowing what to expect); the paid figurants in need of the money regardless of the nature of the work to be performed; and the architectural setting of the gallery conferring its legitimacy to the event.

Spatially, as the relation plays itself out, the wall indexically shifts between the concrete wall of the Tate Modern as an institution, and the wall itself as a more generic 'punishment wall. ${ }^{25}$ During the moment visitors stop to watch, the gallery becomes the amphitheatre from which they, as museum-goers, observe 
the punishment and are brought face-to-face with their role as voyeur. In this specific context it may even be possible that the architecture can, momentarily, make visitors associate themselves with the figurants, as the sun entering from behind cast the shadows of both spectators and the contractuals on the wall together. ${ }^{26}$ Alongside the role of the museum institution and its legitimizing architectural setting, the role, ambiguities, and contradictions of the contract are at the fore. The occupation of this space by the vulnerable on one side, and by the viewers on the other, vividly exposes both the contract and the architectural space in which it is 'performed' to consideration in the larger frameworks in which they operate. In a spatial-institutional analysis then, the work leads us to the terrain already covered - to the legitimizing role played by the architecture of the institution's building in the justification of the immoral or illicit, and as the setting for a codified and socially acceptable form of exploitative ent'art'ainment.

With respect to law, Sierra's work underlines that, as the public, we rarely grant any importance to the fact that 'the notion of the contract' is not only at the very heart of his work, but also central to many other aspects of our lives. In this piece, the contract can be read as a neutral tool, malleable and fiercely efficient in justifying the clearly absurd exploitation of eminently vulnerable human beings. It thus brings up the classical definition of the contract as 'neutral' - and thus specifically brings jurists (in their role as social actors and contract theorists) face to face with the contradictions and the epistemological gaps that they manipulate on a daily basis. The piece also raises important and disconcerting questions for jurists in the fact that the discomfort created for the viewer in Sierra's work is totally unrelated to the contractual nature of the artistic mise-en-scène - despite it being fundamental to the injustices and exploitation at the heart of the work. ${ }^{27}$ In short, it is a piece that clearly illustrates the complex overlaying of a juridical, architectural and social reading of physical space and legal contract.

\section{Conclusions: The legal contract and architecture as social artefacts: A double-tangent}

\section{The Legal Contract}

The range of issues brought up by all these works, for both the jurist and the architect, are clearly multiple, ambiguous and potentially of central importance. At a juridical level, the consideration of the contract within a larger social framework enables us to reposition our interpretation of contracts in the bounds of voluntarism. In the work of Young the seemingly arbitrary nature of the legal shifts in the definitions of nationhood, territorial sovereignty, and the right to define the boundary between one space and another, are all juxtaposed with the equally arbitrary ease with which the artist and the visitor are invited to do so. The potential of the piece to question the legal constricts within which artists operate, and our passivity as a society to the role contracts play in our lives, are all brought up. In the work of Calle the hand that writes the terms of the contract, and the one that accepts them, become one in the same thing but, at the same time, it manages to question issues of equality and the extent to which the contract extends across the boundary of the private and the public realms of our lives. 


\section{Amps}

By bringing to the fore the question of the 'evenness' of the relationship between the parties engaged in the contracts, the work of Calle overlaps with that of Sierra who, in particular, contributes to a critical reflection on contractual theory in this regard - specifically its current incapacity to accommodate personified and socialized individuals. ${ }^{28}$ Enriching the legal perspective, these artistic works have the capacity to question the limits of the role and power of the law, and imply criticism that can shake our faith in the presumed rationality of the contract. Is the contract to be considered solely as an artistic tool a valuable social artefact - or is it, on the contrary, to be considered the ally of a dysfunctional universe that tolerates the absurd contractual involvement of the most vulnerable out of necessity? Typically, the contract is seen as an 'economic good' - an abstract, independent and objective social artefact that carries a demultiplied monological discourse. In the context of the art works discussed here however, what is brought to the fore is the inter-subjective complexity inherent to the synallagma. As such, the study of these artistic uses of the contract enables us to cast light on the inconsistencies through which different parties inevitably appropriate the juridical norms of contract law. It could be said that they bring us into contact with the rigor mortis of the contract.

\section{Architecture}

Similar things can be said with regard what these projects reveal about the social role of architecture in contemporary society. In its constant challenges to what is public or private, intimate or shared, the work of Sophie Calle's, for example, opens up our comprehension of what we consider 'public' and a questioning of the spaces, actions and behaviours we (as a society bound by our passively entered into behavioural contracts) attribute to it. As Calle makes a room on the top floor of the Eiffel tower, or turns a New York phone booth into a habitable space, she asks us to reconsider many issues: our reading of potential occupants, our understanding of the space itself and, indeed, our definition of the city in which the relation between these issues operate. The tensions that the works reveal are intended to invite the reconsideration of appropriate or inappropriate uses of our cities and its spaces. If we take for granted that the public space of the city is one of conformity, Calle's work reminds us it isn't. Similarly, if we take for granted that the city is a place of diversity, her work makes it very clear that certain voices dominate.

In Carey Young's installation, Declared Void, a set of related issues is raised for jurists and architects. Here, a complex imbrication of physical, legal, national and international spaces co-exist in the space created between six lines drawn on the floor and two walls. This installation reveals how easy it is for physical spaces to be experienced differently as a result of even the slightest shifts in our spatial and intellectual frames of references. It also shows our willingness to play with one set of conditions or another; our openness to entering into one contract or another, both passively and actively; and our tendency to accept boundaries as markers of the conditions laid out by externally imposed contracts, rules or regulations. Extrapolated from the installation to the museum/gallery building itself, the same thing can be said to apply at the institutional level in the work of Sierra. In his work the architecture, as it physically delimits the institution, provides a normalizing space within which these shifts in our experience and frame of reference can operate. 
If we focus on how this operates outside the context of a particular work and consider it as a phenomenon of the gallery institution more generally, its walls become the boundary of the 'inside' and 'outside' conditions of these different frames of reference. This is in fact the basic precondition for all the works we have discussed - the gallery becoming the place (inside) for the playful, thoughtful or detached engagement with the messy reality, restrictions and inconveniences of life (outside). Considered objectively and normatively, the architecture of the museum acts as a form of a neutralizing field, in the sense described by Peter Carl - a field against which fragmented pieces and installations (of possibly exploitative art) may be understood and accepted. ${ }^{29}$ Sharing this consideration, all the works discussed here ask questions that resonate far beyond the walls of museum or gallery buildings and can be seen as relevant in all spheres of life that collect around them their built architectural forms - the commercial, the legal and the political, to name but a few of the most obvious. They encourage the architect to consider some of the most mundane, invisible, but also important, forces that regulate our experience of other physical spaces: the power of churches to operate as a safe haven for people facing expatriation; the unwritten spatial and behavioural rules that materializes when people line up for a bus; or our veneration of places of the past even when the physical traces of its buildings and events have disappeared. ${ }^{30}$

\section{'The Double-Tangent'}

In considering the contractual, the architectural - and their combination - in these works, the architect and the jurist constantly waver between the invisible power of the contract and the visible materialization of our spaces of action. It is a process that can be said to focus our attention on the real and sometimes physical consequences of the 'immaterial' contract, and the immaterial consequences that stem from the legitimizing influence of 'material' architectural form. ${ }^{31}$ In examining these works from this dual contractual and architectural perspective, we are also allowed a more comprehensive analysis (in the sociological sense) of the architectural project - the contractual phenomenon specifically - and the conception and operation of social artefacts such as architecture and the contract more generally.

Of course, architects and jurists are aware of the social foundations of their practices in the epistemological sense, but our intersecting perspectives on these artistic works confront us with some very pointed and specific questions. One such question is whether architecture, and our use and understanding of the contract, have become 'complacent'. Do they merely reflect 'the social' status quo and norm rather than engage in forming it, challenging it and remaking it? As social artefacts, both the contract and the architectural project belong to a larger epistemological framework that is understood as contractual and architectural theory. However, they also belong to a world of experiences wherein they have very real implications. By drawing attention to this, these artworks (and this paper) allow us to raise questions about whether we can reinvigorate our use and understanding of these concepts. This double tangential approach allows us to see the installation and gallery setting in contractual terms and the potential implications of the contract - in specific and general terms - on spatial practice. Thus, it allows us to examine architecture and law in the terms of Hannah Arendt's subjective in-between; the space between the contractual and architectural episteme and their phenomenological unfolding. While we have yet to refine the methodological framework that truly belongs to this approach, our contention (as architect and jurist) is that it is in this subjective in-between that social artefacts (whether art works, legal 
contracts of architectural structures) are best interpreted and constructed. Proof of this is that, in the context of these artworks, it has allowed us to identify issues which although in need of be further examination are clearly of crucial importance to the status and employment of the contract and the architectural project as social artefacts today. 


\begin{abstract}
${ }^{1}$ The term "social artefact" has been used in relation to the contract by the sociologist M. C. Suchman. Beyond this common interest in the social constitution and role of the contract, our approach to this notion is distinct from his. See M. C. Suchman, "The Contract as Social Artifact", Law \& Society Review, 37 : 91. We thank Professor Bejarne Melkevik for first placing this text in our mailbox many years ago.

${ }^{2}$ Occupying this peripheral position in a focus on art, some social actors usually left at the periphery of our disciplinary concerns 'emerge from the shadows' and take up central positions in our examination. This, we suggest, differs from the majority of material currently available. While many critical works exist on the renewed consideration of the social dimension of architecture and law, research centered on the intersection of these two fields is rare. One example is Stewart Macaulay, "Organic Transactions: Contract, Frank Lloyd Wright and the Johnson Building”, Wisconsin Law Review 1 (1996): 74-121. Other works do promote an enlarged consideration of the built environment, foregrounding the social production of space in Lefebvre's sense and working from De Certeau's work. For example, some authors have considered the operations of actors from skateboarders to illegal immigrants, reading their impact and visibility in the city. We are thinking of works by authors such as Richard Sennet, Conscience of the Eye: The Design and Social Life of Cities, (New York: Knopf, 1990) and Fall of Public Man (New York: Knopf, 1977) ; Chase Coutts-Smith, Margaret Crawford, and John Kaliski, Everyday Urbanism (New York: Monacelli Press, 2008); Sophie Watson, City Publics: The (Dis)Enchantments of Urban Encounters ( London; New York: Routledge, 2006); Jonathan Hill, Actions of Architecture: Architects and Creative Users (London; New York: Routledge, 2003); and Iain Borden,
\end{abstract} Skateboarding, Space and the City : Architecture and the Body (Oxford; New York: Berg, 2001).

${ }^{3}$ As with the works themselves, we pose questions of relevance to jurists, artists and architects as well as to those outside these 'establishment' fields - to the general public that encounter Young's work, to the prostitutes that take part in Sierra's work or the contracted individual in Calle's work. The public we hope to reach then, is not just an academic public or one defined by a type (e.g. street vendors) or an activity (e.g. cultivation), but rather a disparate public critically brought into friction with the capitalistic world of consumption - against which both architecture and the contract are framed. There are works dealing with and addressing this public, and while none of them address specifically the intersection between law and architecture, they all contribute to a more inclusive consideration of the social public of architecture - whether focusing on the architect's ability to strategically build a more encompassing construction, or focusing on the tactical appropriation of space by diverse publics through direct actions. See Lyn H. Lofland, The Public Realm: Exploring the City's Quintessential Social Territory (New Brunswick; London: AldineTransaction, 1998); Don Mitchell, Right to the city: Social justice and the fight for public space (New York; London: Guilford Press; 2003); Amanda Dargan and Steven J Zeitlin, City Play (New Brunswick: Rutgers University Press, 1990); Aldo van Eyck, , The Child, the City and the Artist: An Essay on Architecture the in-between Realm, eds Vincent Ligtenlijn, Francis Strauven (Amsterdam: SUN, 2008).

${ }^{4}$ Many authors have brought attention to the lack of coherence that characterizes the field at the moment. As examples of the most important French works, see: R. Demogue,. Traité des obligations en général, t. 1. (Paris: Rousseau, 1923); E. Gounot Le principe de l'autonomie de la volonté en droit privé : contribution à l'étude critique de l'individualisme juridique, (Paris: A. Rousseau, 1912); G. Rouhette, Contribution à l'étude critique de la notion de contrat, (th. Paris: 1955); V. Ranouil, L'autonomie de la volonté : naissance et évolution d'un concept, (Paris: PUF, 1980); H. Battifol, "La 'crise du contrat' et sa portée", Arch. phil. Droit 13 (1968): 13-30.

${ }^{5}$ Carey Young. "Published essays \& interviews : Consideration - Carey Young in conversation with Defne Ayas, June 2006". Accessed October 17, 2013. http://www.careyyoung.com/essays/ayas.html.

${ }^{6}$ Ibid.

${ }^{7}$ Ibid.

${ }^{8}$ Ibid.

${ }^{9}$ The Black Painting of Kazimir Malevich was specifically hung across the corner of a room in "The Last Futurist Exhibition 0,10" held at Petrograd (now Saint Petersbourg) in 1915. Echoing the traditional placement of icons in the Greek Orthodox Church, the spatial ambiguity of the corner placement was seen as opening up the possibility of a different temporality - for Malevich, another dimension, for the Orthodox Christians, eternity. This lay beyond the frame, in a space to which the painting or image acted as threshold, but one which no longer really belonged to the reality of the room.

${ }^{10}$ More recently, Cooper has exhibited "Contracting Authority" (2010) and "Report of the Legal Subcommittee" (2010), two works that continue to play on the relation between law, contracts and reality, but now emphasizing the role of representation in the appropriation of different realms of space and time.

${ }^{11}$ Sophie Calle, interview by Michel Guerrin, "Sophie Calle, cigale et fourmi", Le Monde, December 31, 2011.

${ }^{12}$ Ibid.

${ }^{13}$ Indeed, some public art installations work precisely on the premise that in public space public actions are unified. The installation of a giant "tea machine" at the site of the London Olympics in 2012 is an example. This piece brought many people together momentarily around a particular British tradition in which the activity, and its physical location, provided a shared ground for people to engage and interact, apparently equally. 
${ }^{14}$ Bernard Tschumi, Architecture and Disjunction (Cambridge, MA: The MIT Press, 1996) and The Manhattan Transcripts: Theoretical Projects (New York: St. Martin's Press, 1995).

${ }^{15}$ Sophie Calle and Paul Auster, Double Game (New York: Violette Edition / DAP, 1999).

16 "Instructions personelles pour Sophie Calle afin d'améliorer sa vie à New York (parce-qu'elle l'a demandé...)", in Sophie Calle, Gotham Handbook, livre VII, Doubles-jeux (Arles:Actes Sud, 1998).

${ }^{17}$ The notion of the contract is explicitly mentioned by one of the women who agreed to comment on the break up email. A professional lawyer, she compared it to a 'contrat immobilier'. See: Helen Kaplinksy, October 30, 2009 "Head-Wig (Portrait of an exhibition) Selected by Paulina Olowska, Camden Arts Centre, 2009", http://curatingthewords.wordpress.com/2009/10/

${ }^{18}$ In this piece, Calle follows Henri B, spies on him, and finally tries to get a last glance at him as he returns to Lyon. At certain moments throughout this 13 days' long piece, she lies in such close proximity that she could actually touch him. She acts as a chamber-maid cleans, but also spies, copies, photographs, reproduces and reads letters, notes and other personal objects left in the rooms when they are vacated by their unknown users. The chamber maid as artist is voyeur and author of small interferences within the hotel room and by extension the life of its transient guest; the anonymous Venice stroller is a guide, a suspect followed by a shadow, the centerpiece of a work.

${ }^{19}$ Photographs of the performance are available at www.santiago-sierra.com/200014_1024.php. Accessed October 17, 2013.

${ }^{20} \mathrm{As}$ is often the case in the work of Sierra, there are multiple potential readings and their socio-juridical consequences have many facets. Thus, by promoting the artistic character as the cause for the act to justify its legality, the artist clearly brings up to the fore the commercialization of the artistic milieu and the advantage that he himself gains from the exploitation of the performers he pays.

${ }^{21}$ For details on this performance, see " $160 \mathrm{~cm}$ Line Tattooed on 4 People El Gallo Arte Contemporáneo. Salamanca, Spain. December 2000", Tate, accessed October 17, 2013, www.tate.org.uk/servlet/ViewWork? workid=81203\&searchid=13933\&roomid=3688\&tabview=text.

${ }^{22}$ We are borrowing the expression from Edouard Levé, who introduces the French neologism "Divartissement." See Edouard Levé, Particules 14, avril-mai 06.

${ }^{23}$ Video documentation of this performance is available at http://channel.tate.org.uk/media/33799701001. Accessed October 17, 2013.

${ }^{24}$ During an interview integrated to the video presentation of the performance, Sierra explains: "It is not the kind of art that says 'George Bush is a mother-fucker'. Because it creates, in everybody who sees something like that [the idea of] a relationship like brothers: 'We are good people and George Bush is a mother-fucker.' And what I am saying is nothing like that. I am not putting my finger in the responsibility for all of this. And it creates an uncomfortable situation because the people who are watching art are high class or at least high cultured people. And these people become uncomfortable because it is a portrait of themselves." See: Santiago Sierra, Performance : Santiago Sierra, accessed October 17, 2013, http://channel.tate.org.uk/media/33799701001.

${ }^{25}$ For the translation of Peirce's conception of the index in art, see Rosalind Krauss, "Notes on the Index" in The Originality of the Avant-Garde and other Modernist Myths, (Cambridge, MA: The MIT Press, c1986). We are also considering here the potential application of C. S. Peirce's notion of the index in architecture, as discussed in Anne Bordeleau "An Indexical approach to architecture", Footprint Journal 3 (2008): 79-95.

${ }^{26}$ As with the previous piece discussed, here there is a question of the awareness and discomfort of the audience. "Who is being punished?" becomes a question. The visitors are also 'told off' for their desire to seek cultural entertainment in the museum and are thus forced to see in its walls something else than the blank wall of an institution

${ }^{27}$ Other artists, such as Jill Magid, actually put the contract not only at the center of their piece but also at the center of their critical discourse. In a work entitled Auto Portrait Pending, realized in 2005, Magid showed a box with a contract stating that she had an agreement with a company (see www.lifegem.com) to transform the carbon present in the ash of her dead body into a diamond when she would die (see photographs at www.jillmagid.net/AutoPortrait.php). This diamond was then to be mounted on a gold ring. Accompanying the exhibit was the following note: "Make me a diamond when I die. Cut me round and brilliant.

Weigh me at one carat. Ensure that I am real". Daniel McClean, "The Artist's Contract / From the Contract of Aesthetics to the Aesthetics of the Contract", Mousse Magazine 25 (2010). moussemagazine.it/articolo.mm?id=607. Accessed October 17, 2013.

${ }^{28}$ While the paper is rooted in French contract theory, the observations apply to contracts in general.

${ }^{29}$ Peter Carl, "On depth, particular and universal, fragment and field", in Fragments : architecture and the unfinished : essays presented to Robin Middleton. Edited by Barry Bergdoll with Werner Oechslin. (London: Thames and Hudson, 2006).

${ }^{30}$ In this context we can also consider Rachel Whiteread's HOUSE project, perhaps even more powerful and influential now as an 'absence' than it was when constructed.

${ }^{31}$ The museum is important insofar as it provides the institutional context against which the contract-involving artistic performances take place, as distinct from the specific architecture of the building in its social, economical, and cultural context. 


\section{Bibliography}

Battifol, H. "La 'crise du contrat' et sa portee." Archives de Philosophie Droit 13(1968): 13-30.

Bordeleau, Anne. "An Indexical approach to architecture", Footprint Journal 3 (2008): 79-95.

Borden, Iain. Skateboarding, Space and the City: Architecture and the Body. Oxford; New York: Berg, 2001.

Calle, Sophie. "Instructions personelles pour Sophie Calle afin d'améliorer sa vie à New York (parcequ'elle l'a demandé...)". Gotham Handbook, livre VII, Doubles-jeux. Arles:Actes Sud, 1998.

Calle, Sophie and Paul Auster. Double Game. New York: Violette Edition / DAP, 1999.

Calle, Sophie. Interview with Michel Guerrin. "Sophie Calle, cigale et fourmi." Le Monde. December 31, 2011.

Carl, Peter. "On Depth, Particular and Universal, Fragment and Field." Fragments : Architecture and the Unfinished: Essays Presented to Robin Middleton. Edited by Barry Bergdoll and Werner Oechslin. London: Thames and Hudson, 2006.

Coutts-Smith, Chase, Margaret Crawford, and John Kaliski. Everyday Urbanism. New York: Monacelli Press, 2008.

Dargan, Amanda, and Steven J Zeitlin. City Play. New Brunswick: Rutgers University Press, 1990.

Demogue, R. Traité des obligations en général. Paris: Rousseau, 1923.

Digital Museum of Modern Art. "Kazimer Malevich, 'Last Futurist Exhibition’ (1915)." dmoma.org. http://www.dmoma.org/lobby/exhibitions/blockheads/futurist.html. Accessed October 17, 2013.

Eyck, Aldo van. The Child, the City and the Artist: An Essay on Architecture the In-between Realm. Edited by Vincent Ligtenlijn and Francis Strauven. Amsterdam: SUN, 2008.

Goldberg, Rose Lee, ed. PERFORMA - New Visual Art Performance. New York: Performa, 2007. Accessed October 17, 2013. http://www.careyyoung.com/essays/ayas.html.

Gounot, E. Le principe de l'autonomie de la volonté en droit privé : contribution à l'étude critique de l'individualisme juridique. Paris: A. Rousseau, 1912. 
Hill, Jonathan. Actions of Architecture: Architects and Creative Users. London; New York: Routledge, 2003.

Krauss, Rosalind. "Notes on the Index." The Originality of the Avant-Garde and other Modernist Myths. Cambridge (MA): The MIT Press, c1986.

Levé, Edouard. Particules 14, avril-mai 06.

Lofland, Lyn H. The Public Realm: Exploring the City's Quintessential Social Territory. New Brunswick, U.S.A; London, U.K.: Aldine Transaction, 1998.

Macaulay, Stewart. "Organic Transactions: Contract, Frank Lloyd Wright and the Johnson Builidng." Wisconsin Law Review 1(1996): 74-121.

Magid, Jill. "Auto Portrait Pending." Jill Magid.net. http://www.jillmagid.net/AutoPortrait.php. Accessed October 17, 2013.

McClean, Daniel. "The Artist's Contract / From the Contract of Aesthetics to the Aesthetics of the Contract." Mousse Magazine 25 (2010). Accessed October 17, 2013. moussemagazine.it/articolo. $\mathrm{mm} ? \mathrm{id}=607$.

Mitchell, Don. Right to the City: Social Justice and the Fight for Public Space. New York; London: Guilford Press; 2003.

Ranouil, V. L'autonomie de la volonté : naissance et évolution d'un concept. Paris: PUF, 1980

Rouhette, G. Contribution à l'étude critique de la notion de contrat. th. Paris: 1955.

Sennet, Richard. Conscience of the Eye: The Design and Social Life of Cities. New York: Knopf, 1990. ---. Fall of Public Man. New York: Knopf, 1977.

Sierra, Santiago. "160 cm Line Tattooed on 4 People El Gallo Arte Contemporáneo. Salamanca, Spain. December 2000.” Santiago-Sierra.com. http://www.santiago-sierra.com/200014_1024.php. Accessed October 17, 2013.

Sierra, Santiago. "Performance: Santiago Sierra." Bloomberg: TateShots. Tate Modern video, 5:32, April 21, 2008, http://channel.tate.org.uk/media/33799701001. 
Suchman, M. C. “The Contract as Social Artifact.” Law \& Society Review 37 (2003): 91.

"Talking to Strangers - Sophie Calle@ the Whitechapel." Curating the Words.

http://curatingthewords.wordpress.com/2009/10/28/talking-to-strangers-sophie-calle-thewhitechapel/. Accessed October 17, 2013.

Tate Modern. "Santiago Sierra: $160 \mathrm{~cm}$ Line Tattooed on 4 People El Gallo Arte Contemporáneo.

Salamanca, Spain. December 2000.” Tate.org.uk. http://www.tate.org.uk/art/artworks/sierra-160-cm-

line-tattooed-on-4-people-el-gallo-arte-contemporaneo-salamanca-spain-t11852. Accessed October 17, 2013.

Watson, Sophie. City Publics: The (Dis)Enchantments of Urban Encounters. London; New York: Routledge, 2006. 